\section{Information for Employers}

\section{Complying with OSHA's Bloodborne Pathogens Standard}

The Bloodborne Pathogens Standard applies to employees who have

occupational exposure (reasonably anticipated job-related contact with blood or other potentially infectious materials)

The three most common bloodborne pathogens (BBPs) are human

immunodeficiency virus (HIV), hepatitis $B$ virus (HBV), and hepatitis $C$ virus (HCV).

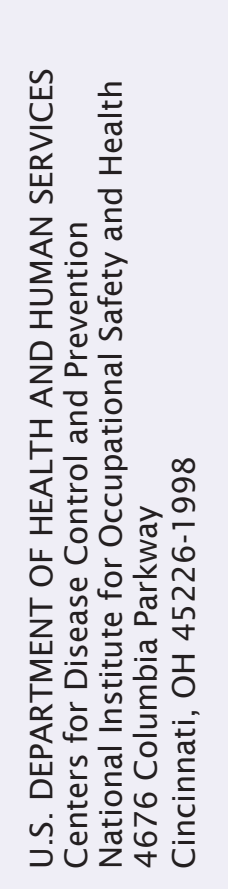

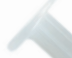

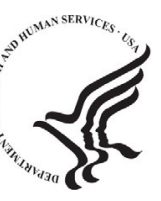

\section{0}

Workplace

Workplace
sarely and Hoolith

MOSHA OSHA

\title{
Resources for Employers
}

This flyer is being sent to employers as an aid to understanding and complying with the Occupational Safety and Health Administration (OSHA) Bloodborne Pathogens Standard. This standard seeks to prevent serious occupational infections among employees

OSHA

Bloodborne Pathogens and Needlestick Prevention

www.osha.gov/SLTC/bloodbornepathogens/ index.html

OSHA Federal and State Plans Offices www.osha.gov/html/oshdir.html www.osha.gov/dcsp/osp/index.htm

CDC

NIOSH Bloodborne Pathogens Topic Page www.cdc.gov/niosh/topics/bbp

Protecting Healthcare Workers from Bloodborne Pathogens

www.cdc.gov/ncidod/dhqp/wrkrProtect_bp.htm

Publications/Web Documents Sharps Safety Workbook (2004)

www.cdc.gov/sharpssafety

Model Plans and Programs for the OSHA Bloodborne Pathogens and Hazard

Communications Standards (2003)

OSHA Publication No. 3186

www.osha.gov/Publications/osha3186.pdf

Medical \& Dental Offices: A Guide to

Compliance with OSHA Standards (2003)

OSHA Publication No. 3187

www.osha.gov/Publications/osha3187.pdf

NIOSH Alert: Preventing Needlestick Injuries in Health Care Settings (1999)

DHHS (NIOSH) Publication No. 2000-108

www.cdc.gov/niosh/2000-108.html
Safety Device Information and

Device Evaluation Tools

University of Virginia International Healthcare

Worker Safety Center

www.healthsystem.virginia.edu/internet/epinet/ safetydevice.cfm

ECRI Institute www.ecri.org

Needle-Free Injection Technology www.cdc.gov/vaccinesafety/vaxtech/nfit

International Sharps Injury Prevention Society www.isips.org/safety_products.htm

Association of Needle-Free Injection Manufacturers www.anfim.com

Premier, Inc. Sharps Injury Prevention www.premierinc.com/needlestick

TDICT Project

www.tdict.org/performance.htm www.tdict.org/evaluation2.html

Mention of any company or product does not constitute endorsement by the National Institute for Occupational Safety and Health or the

Occupational Safety and Health Administration In addition, references to Web sites external to NIOSH do not constitute NIOSH endorsement of the sponsoring organizations or their programs or products. Furthermore, NIOSH is not responsible for the content of these Web sites. 


\section{OSHA's Free On-Site Consultation} Service

If you need help, OSHA offers a free, on-site safety and health consultation service.

The On-site Consultation Program is a broad network of occupational safety and health services funded primarily by federal OSHA but implemented by state governments using highly qualified occupational safety and health professionals.

The On-site Consultation Program is completely separate from OSHA enforcement operations

A consultant does not issue citations or impose penalties.

Consultation is a confidential service. For more information on the On-site Consultation Program visit:

www.osha.gov/dcsp/smallbusiness/consult.html. The consultant can:

- Help you recognize hazards in your workplace.

- Suggest approaches or options for solving a safety or health problem.

- Identify sources for further help.

- Provide a written report that summarizes their findings.

- Assist you in developing or maintaining an effective safety and health program.

- Offer training for you and your employees.

Request this service by calling or writing the On-site Consultation Program in your state. For contact information, visit:

www.osha.gov/dcsp/smallbusiness/ consult_directory.html.

\section{Exposure Control Plan}

Identify job classifications, tasks, and procedures where there is occupational exposure.

Establish a written Exposure Control Plan and make it available to employees. Review and update it annually.

\section{Safety Devices}

Evaluate medical devices with engineered sharps injury protections (safety devices)

Use appropriate, effective, and commercially available safety devices.

Involve front-line employees in the evaluation and selection process.

Document the evaluation and selection of safety devices annually.

\section{Hepatitis B Vaccination}

Offer free hepatitis B vaccinations to all employees with occupational exposure to blood or other potentially infectious materials (OPIM).

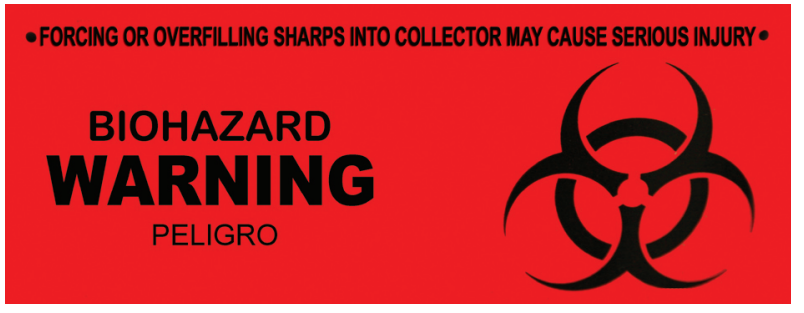

\section{Other Controls}

Ensure that employees comply with Universal Precautions.

Use engineering and work practice controls to eliminate or minimize employee exposure.

Provide and ensure the use of appropriate personal protective equipment, such as gloves, gowns, lab coats, face shields or masks and eye protection, and mouthpieces, resuscitation bags, pocket masks, or other ventilation devices.

Ensure that contaminated sharps are disposed of in proper sharps disposal containers.

\section{Post-Exposure Incident Procedures}

Establish a procedure for post-exposure evaluation and follow-up.

Document the route of exposure and other circumstances. Identify the source individual where feasible.

Offer post-exposure medical evaluation by a healthcare professional at no cost to employees.

Test the source individual's blood for BBPs where possible, and test the exposed employee's blood after consent is obtained.

Ensure the provision of post-exposure medication when medically indicated and as recommended by the Department of Health \& Human Services.

\section{Training}

Train occupationally exposed employees at initial assignment and at least annually by a knowledgeable person.

Training must include a number of elements, such as:

- An accessible copy of the BBP standard (29 CFR 1910.1030).

- Information on the epidemiology and symptoms of bloodborne diseases.

- Information on modes of transmission of BBPs.

- Description of employer's Exposure Control Plan and how to get a copy.

- How to recognize tasks that may involve exposure to blood or OPIM.

- Use and limitations of methods to reduce exposure, including engineering controls, work practices, and personal protective equipment.

- Information on the hepatitis B vaccine.

- What to do and whom to contact after an exposure.

- Information on post-exposure evaluation and follow-up.

- An opportunity for interactive questions and answers. 